霊長類研究 Primate Res. 30 : 79-93, 2014 (doi : 10.2354 / psj.30.007)

\title{
特集 霊長類を巡る種間関係（2）
}

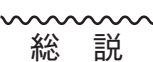

\section{霊長類をめぐる生物間関係と生態系における役割}

\author{
辻野亮 $^{1)} \cdot$ 湯本貴和 ${ }^{2)}$
}

1）奈良教育大学自然環境教育センター

2) 京都大学霊長類研究所

\section{はじめに}

種は生態系の中で他の種とさまざまな相互 作用を授受する関係を持つ。その中でも多様 な被食・捕食相互関係によって構成される食 物網は，生態系の中でもつとも根本的で重要 な関係である。種は食物網の中でいくつかの 栄養段階に属する。植物は光エネルギーを受 けて炭水化物を光合成する生産者であり, 生 態系におけるエネルギーと物質の流れの基礎 を占める。第二栄養段階の第一次消費者は主 に植物を専食する植食動物である。第二次消 費者は草食動物を捕食し, 消費する肉食動物 である。さらにそれらを捕食する高次消費者 と呼ばれ，植物と動物の両方を採食する動物 は雑食動物と呼ばれる。反忽亜目や奇蹄目な どの有蹄獣は顎や臼歯, 胃や腸を特殊化して 植物食に特化している動物であり, 速く走っ て肉食獣からの捕食を免れるための脚や巨大 な体を進化させている。また, 食肉目は肉食 を主とする動物群で，しなやかに素早く走る ための体躯や獲物を捕らえるための犬歯と鉤 爪, 肉を噛み切るための裂肉歯や顎関節が特 殊化している。それらに対して霊長類では形 態的な特殊化の度合いが低く, 特殊化した特 徵が欠けている。霊長類の代表的な特徵は立
体視，拇指対向性，大脳皮質の巨大化，長い 寿命, 雑食に適した歯や顎関節, 木を登るの に適した比較的細身の体躯が挙げられる（松 本 2013)。霊長類は確かに中枢神経こそ高度化 しているが，むしろ全体の体制を原始的にと どめたからこそ, 脳の発展を図ることができ たグループである（遠藤, 2002）。その意味で, 肉食獣や有蹄獣のような, 中枢神経を後回し にして特殊化の道に入ったものとは全く異な り, あくまでも霊長類は, 特殊化の程度の低 い基本体制に支えられている（遠藤，2002）。

一方で霊長類は体サイズや生態的に見ると 驚くほど多様で変化に富んでいるために，い ろいろな生態的位置を占めることができる。 たとえば, 体重の重い種は果実や植物の葉を 主に採食し, 逆に体重の軽い種は昆虫や小動 物などを採食する（Kay, 1984）。また一方で他 の哺乳類を捕食することもあるし, 時には寄 生虫に寄生されることで体の一部を採食され るときもある。このように霊長類は生態系の 中でさまざまな位置を占めると考えられ, 特 に熱帯林では森林における霊長類のバイオマ スが大きいので, 霊長類は森林の生態プロセ スにおいて大きな影響と役割を占めており, 生態系における霊長類のさまざまな生物間関 係を対象とした研究がなされてきた。霊長類 
は主に赤道付近の熱帯林を中心として生息し ており, 熱帯林では多数の種が同所的に分布 しているために (Eeley \& Foley, 1999), 霊長類 同士の種間関係（混群や捕食）を対象として 研究することができる，本稿では，1）霊長 類をめぐる生物間関係を整理し，2）生態系 研究の中で霊長類を材料として用いる場合の 長所短所を示し，3）霊長類による生態学的 研究の可能性を考察することを目的とする。

\section{霊長類と他の生物との種間関係}

生態系における霊長類と他の生物との種間 関係は捕食被食関係だけではない。適応度を 基にして直接関係を整理すると以下の 6 つの 関係に集約される。すなわち，どちらかが利 益を得てもう片方が不利益を被る場合（捕食 被食関係), どちらも不利益を被る場合（競争 関係)，どちらかが不利益を被るのにもう片方 が特に利益も不利益も得ない場合 (片害関係), 両方が利益を受ける場合 (相利共生関係), ど ちらかが利益を受けてもう片方は不利益を被 らない場合 (片利共生関係), さらに同所的に 生息していても特に直接関係を持たない場合 (無関係) である（図 1 )。以下に片害関係と 無関係を除いた 4 つの種間関係を概説する。

\section{捕食被食関係}

生態系の種間関係の中で最も中心的な関係 は食う食われるという種間関係であり，生態 系構成員である生き物が何を採食するのかは, 生態学の中で大きな話題の一つである。野生 霊長類の食性には植食性から雑食性まであり, さまざまな生き物を食べている（Sailer et al., 1985)。樹木の葉を林冠で採食する葉食と繁殖 器官である果実や種子を採食する果実食（種 子食を含む)，菌類の子実体（キノコ）を採食 するやキノコ食では, 植物や菌類の生残や生 長に対して多少負の影響を与えるだろう。た だし，過剰に葉が食べられてしまうと樹木が 光合成できずに枯死してしまう可能性はある
し（Chapman et al., 2013），果実を採食する際 に種子が破壊されるならば，親の生残生長に は無関係ではあるものの, 親の適応度が低め られ, 子の生残は阻止される。一方で果実食 とキノコ食では種子散布と胞子散布によって 植物や菌類の適応度を上昇させることもある。 エスキモーのような肉食文化に属する人類を のぞいて (Draper, 1977), 霊長類には純粋な肉 食種はいないものの, 昆虫などの無脊椎動物 や脊椎動物を捕食する場合もある。この場合 には, 捕食された動物は死亡する。このように, 霊長類は採食行動を通じてさまざまな分類群 の生物に影響を与えている。

\section{葉食}

アカコロブス (Procolobus badius) (Mowry et al., 1996) などのコロブス類, ハヌマンラングー ル (Semnopithecus entellus) (Newton, 1992) や Trachypithecus spp. (Carton, 1999) などのラン グール類, テングザル (Nasalis larvatus) (Matsuda et al., 2011）などは, 植物の葉や茎, 根などの 繊維質を常食とする葉食性霊長類である。有 蹄類が地上でやっているのと同様のことを, 葉 食性の霊長類は樹上で行っている。種子散布 過程と比べて見過ごされがちだが，葉食によっ て樹木が枯死したり繁殖が阻害されることで, 霊長類が生態系エンジニアとして機能する可 能性がある (Chapman et al., 2013)。

樹上生活を得意とする霊長類にとって, 樹 木の葉は森林においてきわめて豊富にあるも のの，栄養的には必ずしも豊かであるとはい えない。そこから最大限の栄養を得るために, 特にコロブス類やラングール類は葉食に特化 しており，あたかも反忽亜目のように，胃を 複胃に進化させて植物䋊維からエネルギーを 吸収する仕組みを持っている（Lambert 1998; Carton, 1999)。コロブス類のような葉食性霊長 類のバイオマスは，植物の質がよい，すなわ ち繊維含有量に対してタンパク質が多い葉が 多い森林ほど増加する（Waterman et al., 1988; Oates et al., 1990; Ganzhorn, 1992)。 


\section{果実食}

ニホンザル (Agetsuma \& Nakagawa, 1998; Hanya, 2004; 辻, 2012) やグエノン類 (Cercopithecus) (Cords, 1986) をはじめとして 多くの霊長類は，果実や種子を好んで採食す る。ただし，森林に常に果実があるとは限ら ないので，果実食性であったとしても果実の 乏しい季節には葉食に切り替えて食物資源の 㛜しい時期を乗り越える種が多い。たとえば, 1 年を通じた直接観察が行われた金華山と屋久 島でニホンザル (Macaca fuscata) の食性を比 較すると, 採食品目に季節変動があるだけで なく, 同じニホンザルでありながら金華山で は種子や堅果類の採食時間が最も長く，屋久 島海岸部では果実, 屋久島ヤクスギ林ではむ しろ植物の葉や茥, 根をよく採食している (Agetsuma \& Nakagawa, 1998; Hanya, 2004)。森 林における果実生産量の多寡や季節変動は霊 長類のバイオマスを決定するのに重要なパラ メタとされており, 森林全体の結実量が下が ると霊長類バイオマスは減少し, 季節性が強 くなると霊長類種数は減少する（Stevenson, 2001; Hanya et al., 2011)。

果実食霊長類は, 果実の果肉部分だけを食 べて種子を吐き戻したり, 腸を通過させて糞 と共に散布することが知られている。しかし ながら，果実食者と種子食者は表裏一体で， ある植物種にとっては種子散布者であったと しても別の植物種では種子破壊者となりうる。 たとえば，屋久島の西部低地林では，八ゼ， キ (Toxicodendron succedaneum) やカラスザン ショウ (Zanthoxylum ailanthoides), アカメガ シワ(Mallotus japonicus), クマノミズキ(Cornus macrophylla) などの果実はニホンザルに種子 ごと破壊されてしまう。種子破壊するかどう かは季節によっても異なり，屋久島の登熟前 のタブノキ (Machilus thunbergii) は種子が採 食されるものの, 熟すと果肉が食べられて吐 き戻し散布が行われる。ニホンザルでは, 果 実と種子のサイズによって果実と種子をどの ように取り扱うかがおおむ秋決まっており，
果実サイズに比して果肉が多いと種子散布さ れやすく, 吐き戻し散布か糞散布かは種子サ イズによって決まる（Otani \& Shibata, 2000）。 また, 噛み砕かれる割合も種子サイズに影響 を受けることも知られている (Tsuji et al., 2011)。

\section{脊椎動物の捕食}

ヒヒ類 (Papio spp.) やチンパンジー（Pan troglodytes）のように体の大きい霊長類はしば しばさまざまな脊椎動物を捕食するし, その 他の霊長類でも観察事例数は少ないものの春 椎動物を捕食することが知られている (Butynski, 1982)。二ホンザルでも鳥類の卵や 爬虫類, 両生類を捕食することが知られてい る（Suzuki et al., 1990; 西川, 2011)。チンパン ジーでは, 霊長類のスーティーマンガベイ (Cercocebus atys) やグエノン類 (Cercopithecus spp. ), コロブス類 (Colobus spp.), アヌビス ヒヒ (Papio anubis), ガラゴ類 (Galago spp.), 有蹄類のブルーダイカー (Cephalophus montieola) やスニ (Nesotragus mosehatus), ブッ シュピッグ (Potamochoerus porcus), ブッシュ バック (Tragelaphus seriptus), 辪歯類, センザ ンコウ (Manis tricuspis), マングース (Iehneumia albieauda), 八イラックス (Heterohyrax brueei)， 八ネジネズミ (Rhynchocyon cirnei) な どの幅広い獲物を捕食する（Wrangham \& Bergmann-Riss, 1990; Noë \& Bshary, 1997)。レッ ドテイルモンキー(Cercopithecus ascanius)では, 鳥類の捕食事例がある（Furuichi, 2006)。しか しながら, 肉食は栄養的には高タンパク質で あるが, 確保しにくいために, 霊長類の中に 完全な肉食の種はいない。

チンパンジーは同所的に生息しているアカ コロブスを集団で狩猟して捕食するために，ア カコロブス個体群に多大な影響を持つと言え る。たとえば，ンゴゴ (ウガンダ) では，チ ンパンジーはアカコロブスの個体数の平均 $3 \%$ を捕食する（Mitani \& Watts, 1999）。ゴンベ国 立公園（タンザニア）では，チンパンジーの 
捕食が存在しないとすると，アカコロブスの 個体数は 10 年間で 2 倍になると推定されてい る（Stanford, 1998)。さらに，霊長類であるチ ンパンジーが霊長類であるアカコロブスを捕 食する現象を調査対象とすることで, 捕食者 側からみた捕食戦略と被食者側からみた対捕 食者戦略の行動や社会, 生態の進化について 考察を行うことも可能である（五百部，2000）。

\section{昆虫食}

小型の霊長類の中には, 昆虫を主とした無 脊椎動物や小型脊椎動物を捕獲して採食する 種もいる。たとえば，スラウェシ島のスラウェ シメガネザル（Tarsius spectrum） はほぼ昆虫食 であり，餌資源の豊富な雨期には直翅目や鱗 翅目の昆虫を採食し, 餌資源がそしい乾期に はそれらに加えて鞘翅目や膜翅目の昆虫も採 食する（Gursky, 2000; Gursky, 2002）。中・大型 の霊長類ではエネルギー要求量と体重の関係 から昆虫食は一般的ではないものの, 葉食霊 長類を除く多様な霊長類によって昆虫は採食 されている(布施，2013）。たとえば，チンパ ンジーやゴリラは道具を用いてアリを集めて 採食する（McGrew, 1974; Watts, 1989; Yamagiwa et al., 1991)。

倒木や枯木などの粗大木質リター (CWD : coarse woody debris）に生息しているような甲 虫の幼虫やアリなどを霊長類が探す過程で CWD を破壊すると，それらを生息の場として いる生物, たとえば上記の昆虫や小型脊椎動 物, 菌類, 植物などの生息場が失われてしまう。 また，霊長類に破壊されなければ長い時間か けてゆっくりと物理的に分解されて栄養塩循 環してゆくはずが，破壊されることで栄養塩 循環を促進する可能性がある。

\section{キノコ食}

霊長類はマイナーな品目であるキノコを採 食する場合もある。南米産の小型霊長類ゲル ジモンキー（Callimico goeldii） は採食時間の 63\%を費やしているものの，キクラゲなど 4
種類の限られたキノコのみを採食している (Hanson et al., 2003)。菌類の細胞壁は複雑な 炭水化物で構成されていておそらく消化でき ないし, 窒素は細胞壁や消化不可能な胞子に あり，キノコは質の低い栄養源であるはずで ある（Johnson, 1996)。にもかかわらず，高栄 養な餌資源を必要とする小型霊長類が採食し ているのは不可解である。実際, 菌類を採食 することが知られている 22 種の霊長類のうち ほとんどが採食時間の $5 \%$ 未満しか費やしてい ない（Hanson et al., 2003)。

一般に菌類の子実体であるキノコは時間的 空間的に不均質でいつどこでどれくらい採食 できるかを予想することが難しい。採食事例 を観察できたとしてもキノコの種同定は難し く, しかも霊長類はキノコを残さず食べてし まうことが多いため, キノコ食はあまり研究 されていない。もしかしたら, キノコは林床 の茶色い色合いの中で赤や黄, 白, 紫などの 色合いで目立つことで, 霊長類に発見されや すくしているのかもしれない。キノコ食はマ イナーな研究分野ではあるものの, 新たな視 点を設けることで極めて興味深い知見が得ら れることを, 澤田 (2014; 本号) は詳しく解 説している。

\section{被食}

霊長類は捕食者であると同時と被食者とも なりうることがあり, チーターやライオン, ヒョウ，八イエナなどの大型食肉目動物や大 型の爬虫類や猛禽類によって捕食される場合 がある（Isbell, 1990; Mitani et al., 2001）。たと えばアンボセリ国立公園（ケニア）の降水量 の少ないサバンナでは, ヒョウ (Panthera pardus) がサバンナモンキー (Cercopithecus aethiops）を捕食することで, 霊長類の個体群 に影響を与えている（Isbell, 1990）。サバンナ モンキーが捕食の危険にさらされるとアラー ムコールを頻発するようになる。一方，樹上 性のコロブス類がチンパンジーによる捕食の 危険が迫ると, チンパンジーとの距離や植生, 
地域によって異なるが，警戒声を出すか，隠 れるか，逃げる（五百部，2000）。さらに，マ ハレやゴンベでは襲撃されれば反撃に出るこ ともある。霊長類の被食に関しては 5 つの傾 向が知られている (Isbell, 1994)。第一に，小 型の霊長類は大型のものに比べて被食される 可能性が高い。第二に, 不慣れな場所では捕 食される可能性が高まる。第三に，樹上性の 霊長類は，林縁や林冠上部などのように彼ら の身が晒されやすい場所においては捕食の可 能性が高まる。第四に, 肉食性哺乳類による 捕食はしばしばエピソード的である。第五に， 地上性の霊長類は樹上性のものに比べてあま り捕食されない。

\section{寄生}

霊長類は多様な内部寄生虫・外部寄生虫の 宿主となりうる。外見上はわかりにくいが， 寄生虫は霊長類に寄生することで霊長類の体 の一部を採食し, 霊長類の生態に影響をもた らしうる。外部寄生虫であるシラミを採食す る行為は（座馬, 2013), 霊長類の捕食者の捕 食ともいえ, 食物網の中で複雑な位置を占め ることになる。また, 寄生虫によって霊長類 が寄生される場合には，霊長類が支払うコス 卜は場合によりけりで，ほとんど影響しない ほじ小さい場合から, 病気を誘発して死に至 る場合まである。

霊長類と寄生虫との相互作用や寄生虫の自 然史を研究することは，霊長類が人間に対す る潜在的な感染性病原体の伝達媒体となりう ることから非常に重要である。さらに，寄生 虫が霊長類に生態的な影響を与えているから こそ, 寄生虫の生態学的な研究をすることに よって霊長類の社会に迫ることができるはず である。たとえば, ニホンザルでは外部寄生 虫であるシラミをとるためのグルーミングに よって社会関係が築かれている。単純なモデ ル系を構築し, 霊長類宿主と寄生虫の関係を 追及することは有意義な取り組みであろう

(MacIntosh, 2014 ; 本号)。

\section{競争関係}

霊長類が他の生物と競争関係にある場合に はどちらも不利益を被る。対象となる霊長類 と他の生物との関係があるときに，ともに適 応度を下げるような状況は競争関係にあると 言える。霊長類が採食するものは, 果実や葉, 動物質であり, これらの餌資源はさまざまな 鳥類やその他の哺乳類と重なっているために, 潜在的な種間競争関係が生じていると想定さ れる (Payne, 1980)。資源をめぐる種閒競争は 霊長類の社会と個体群を形成するうえで重要 な影響をあたると考えられるものの, 同所的 に他種が生息できる生態プロセスとメカニズ ムに焦点を当てた実証研究は難しい。霊長類 の競争関係では, 別の種との競争よりも同種 内のオスオス間競争やメスメス閒競争, グルー プ間競争がよく検討されている（Strier, 2011）。 たとえば, ニホンザルは果実をめぐって群間 競争が生じている（Suzuki et al., 1998）。

競争関係になる他の動物は比較的, 対象霊 長類と体サイズが近く, 採食品目や活動場所が 似通っている。仮に競争関係にある霊長類と他 の動物が資源をめぐって対立した場合には，ど ちらかが追い払われるか, 闘争でどちらかに決 まるか，同種なら順位によって決まるだろう。 体サイズに差があれば，より大型の動物が食べ 続けると考えられる。多種類の霊長類が生息す るような森林では, 他の霊長類が競争相手とな る場合が多いだろうし，そもそも同種他個体と 競争することが多いかもしれない。もし同じよ うなものを食べていても体のサイズが大きく 異なっていたら, 時間的な回避や場所的な回避 が起こることで, 敵対的な競争関係は顕在化せ ずに済まされるだろう。

地上で植物を採食する動物は多い一方, 樹 上で葉を採食する哺乳類は少ないので, 樹上 性葉食霊長類に食物をめぐる競争関係はほと んどない。さらに, 森林での葉の餌資源はほ とんど無尽蔵であることからも，葉食霊長類 の採食をめぐる競争は起こらないと考えられ る。 
果実を採食する霊長類は, クマ類やジャコ ウネコ類, コウモリ, 鳥類などと樹上で果実 をめぐる資源消費型の競争をしている。大井 （2013）は，ニホンザルとツキノワグマの消費 型競争について多方面から考察している。さ らに同じ霊長類どうしでも果実をめぐる競争 関係にある場合があるだろう。たとえば，チ ンパンジーとゴリラは共に果実を採食するこ とが知られているので, それらが同所的に存 在する場合には果実をめぐって競争が生じる はずである。しかし実際には採食行動を変え ることで果実をめぐる闘争が回避されている ようである (Tutin et al., 1991; Stanford \& Nkurunungi, 2006)。果実が少なくなるとゴリ ラは群れを保ったまま，まとまった量のある 別の餌資源（たとえば地上性草本）に移動す るのに対して，チンパンジーは季節を問わず 小さなパーティーに分かれて森林内に散在す る果実を採食する。

地表において霊長類が落果を探して採食す る場合には, 觢歯類や有蹄類, 中小型の日和 見的な果実食性食肉類が競争相手となるだろ う。ジャコウネコは樹上でも活動するので, 樹上でも霊長類の競争相手となりうる。二ホ ンザルは樹上でさまざまな果実を採食するが, その一方で果実の少ない冬の間には地表に落 ちた堅果類を探して食べており，同じように して堅果類を採食する縭歯類やニホンジカと 資源消費型の競争することになる。

\section{相利共生関係}

第四に相利共生関係が挙げられる。霊長類 が関係する相利共生関係としては, 種子散布 や胞子散布, 混群形成が挙げられる。

基本的に植物は動くことはできない。生活 史の中で分布拡大寸るチャンスは花粉散布と 種子散布の二回だけである。種子散布は植物 個体群動態や空間分布構造にとって重要な意 味を持っている (Nathan \& Muller-Landau, 2000; Wang \& Smith, 2002)。植物にとって親木 の樹冠の下に種子が散布されてしまうと, 樹
種特異的な病原菌や高い種子・実生密度に依 存した死亡率によって生残する可能性が低く なる。そのため, 植物は様々な形で種子を遠 くへ散布させる。種子に果実食者が好むよう な果肉を付けることで, 動物によって食べら れ動物がよく利用するような場所に散布させ る方式がある。むしろ果実に果実食者にとっ ての報酬を載せることで母樹から運ばれると 種子は生残する可能性が高まる。

多くの植物は種子散布を多くの果実食動物 種（たとえば，觢歯類，ゾウ，霊長類，果実 食性食肉類, コウモリ，鳥類，爬虫類，アリ など）に依存している。特に熱帯林ではバイ オマスの大きな霊長類は種子散布に大きく寄 与すると考えられる (Bravo \& Zunino, 1999 ; Terborgh, 1986)。たとえばコロンビアでは, ウー リーモンキー (Lagothrix lagothricha) は 1 日 平方キロメートルあたりで 25,000 個もの種子 を散布することができるし（Stevenson, 2000）， コスタリカではクモザル (Atleles geoffroyi) と オマキザル (Cebus capucinus) は 1 日平方キ ロメートルあたりで 5,600 種子を散布させるこ とができる (Chapman, 1989; Chapman \& Onderdonk, 1998)。霊長類が樹木で果実を採食 し, 糞や煩袋を経由して種子を散布すること で，植物の種構成や分布パタン，森林更新な どが影響を受ける（Garber, 1986; Julliot, 1997; Poulsen et al., 2001 ; Tsujino \& Yumoto, 2009)。 果実食霊長類は果実を異なる方法で取り扱う。 すなわち, 果実を噛んで吞み込み種子を破壊 したり，果肉と種子を吞み込んで後に粪とし て排泄されたり，あるいは果実の果肉部分だ けを食べて種子を口から吐き戻す（Corlett \& Lucas, 1990)。このような果実と種子取扱い方 法によって種子散布距離や種子散布場所のバ リエーション, 種子散布の方法 (はき戻し／糞） が異なってくる (Yumoto et al., 1998; Lambert, 1999)。種子がどこにどのように散布されるか は, 樹木の分布パタンや個体群動態などに大 きな影響をもたらす（たとえば，Dominy \& Duncan, 2005; Tsujino \& Yumoto, 2009)。 
キバレ国立公園（ウガンダ）の森林では霊 長類の生息しない森林における林床の実生密 度は霊長類の生息する森林におけるそれと比 較して小さく, 霊長類が樹木の種子散布に大 きく貢献していることが推測され，霊長類の 生物関係が損なわれることで森林の生態系プ ロセスに負のカスケード効果が表れると考え られる (Chapman \& Onderdonk, 1998)。ニホン ザルの生息する屋久島と生息しない種子島で ニホンザルとヒヨドリによるヤマモモの果実 持ち去り量を調べた寺川ほか (2009)によると, 50 年前にニホンザルが絶滅した種子島では果 実はほとんど持ち去られず，種子散布者とし てのニホンザルの代替としてヒヨドリは機能 しなかった。このように霊長類は種子散布で は重要な役割を演じており, 特に霊長類のバ イオマスの大きい熱帯林では，霊長類が失わ れることで森林生態系の重要な機能が大きく 損なわれて森林更新が阻害される。ある種に とっては霊長類に種子散布されるか否かは大 きな生残要因になるだろう。霊長類が果実を 採食することで種子散布するという過程を経 て森林を維持し，それによって他の生物種が 生息することができる。それゆえ，人為的攪 乱を受けている森林の植生回復に向けた種子 散布者の役割は重要であるだろう（佐藤, 2014 ; 本号)。

植物が自律的に移動することができないの と同様に，菌類も自分では移動することがで きないために, 胞子散布が重要な位置を占め る。多くの外生菌根菌類は地下部に子実体を 形成するために, 胞子散布を哺乳類に依存し ている（Johnson, 1996)。つまり, 菌食哺乳類 と外生菌根菌類は相利共生関係にあって森林 生態系における菌類多様性を維持していると 考えられる。さらに外生菌根菌類は菌根で宿 主樹木と共生関係にあるために, 森林生態系 における菌食哺乳類の影響力は樹木の生産力 や多様性にまで拡張されるかもしれない (Johnson, 1996)。キノコを採食する霊長類も， キノコを採食することで菌類の胞子散布を介
して菌類だけでなく樹木にまで影響を与えて いると類推され，霊長類の胞子散布者として の可能性が興味深い（澤田，2014; 本号)。

霊長類が他の動物種と行動をともにして混 群を形成する関係も共生関係の一つと考えら れる (Begon et al., 1996; Stensland et al., 2003, 辻，2008）。異なる哺乳類の動物種が混群を形 成する理由は 3 つに整理できる（Stensland et al., 2003; 辻, 2008)。第一に, 混群を形成する ことで食物の発見効率が上昇したり，採食効 率が増加したり，本来採食できない食物が利 用可能になることで，採食に関する利益が上 昇するからである。たとえばゲルジモンキー (Callimico goeldii) は, 遊動域のどこに熟した 果実が実っているかをよく把握している Saguinus 混 群 (Saguinus fuscicollis とS. labiatus) と遊動を共にすることで，食物の発 見効率を高めているようだ（Porter, 2001）。第 二に，混群を形成することによって，捕食者 に薄めの効果や混乱効果をもたらし, さらに 多くの目と耳によって警戒効率が向上するこ とで，被食に関する不利益の低下を期待でき るからである（FitzGibbon, 1990）。たとえば, シロクチタマリン (Saguinus labiatus) とキイ ロアタマタマリン（S. fuscicollis） は，混群を 形成することで捕食者警戒の効率を向上させ ているようだ (Hardie \& Buchanan-Smith, 1997）。第三に，混群を形成することにより， ホームレンジの拡大やテリトリの防衛を容易 にする一方で，繁殖面での競争を低下させる という社会・繁殖面での利益の上昇が期待で きるからである。

ところで，混群は多様な種で記載されては いるが，細かい行動研究は霊長類を除いて稀 である（Stensland et al., 2003）。これまでに公 表された霊長類と他の動物の混群についての 研究の多くはデータが客観的な手法に基づい て収集されておらず，博物学的な記載の域を 出ていない（辻，2008）。単に餌資源の分布パ タンなどに多種が同調して反応したことによ る一時的な混群現象なのか，永続的で適応的 
な現象であるのかはよくわかっていない。ま ずは多種随伴現象が機会的な現象でないこと を確認し，個体の行動が混群によってどのよ うな影響を受けているかを明らかにしないと いけない（Stensland et al., 2003）。今後は，観 察された混群現象が霊長類ないしパートナー となる動物のいずれか, あるいは双方の生活 に及ぼす影響の程度を適応度の観点から定量 的に評価し, この関係の適応的な意義を追及 していくことである（辻，2008）。

\section{片利共生関係}

第五に片利共生関係が挙げられる。霊長類 が関係する片利共生関係としては, 落穂ひろ い行動（gleaning）が挙げられる。落穂ひろい 行動とは, 霊長類が樹上から落とした食物（果 実, 種子, 葉, 枝など）を, 地上性の, 哺乳 類が採食するという関係である（辻，2008）。 これは, 地上性哺乳類・鳥類が本来利用でき ない樹冠の食物資源を霊長類が供給するとい う関係で，前者にとって採食に関する利益の 上昇をもたらす一方で霊長類は特に利益も損 失もない（辻，2008）。たとえばハヌマンラン グールとアクシスジカ (Axis axis) やニホンザ ルとニホンジカ (Cervus nippon), サバンナモ ンキーとブッシュバック (Tragelaphus scriotus) などの間で, 霊長類が樹上から落と した枝葉や果実を地上性の哺乳類が採食して いた（Elder \& Elder, 1970; Newton, 1989; Newton, 1992; Majoro \& Ventura, 2004; Tsuji et al., 2007; Agetsuma et al., 2011)。逆に, 霊長類 以外の哺乳類が霊長類に食物を供給するとい う関係は見出だされていない（辻，2008）。

\section{生態系研究の中での霊長類研究}

\section{長所と短所}

霊長類研究の大きな特徵は, 直接観察によ る霊長類の個体識別が可能で, 個体ベースの 細かい行動や生態的プロセスに迫ることがで きることである。霊長類の多くは昼行性であ
り，人になれやすい。農作物被害を起こして いる群れでなく，地形が極端に険しくなけれ ば，人に馴らす努力をすることで，通常は容 易に直接観察できるようになる (半谷, 2008)。人為的影響をほとんど受けていない森 林で，そのような調査が可能な場所として， 国内では下北半島，金華山島，白山，幸島， 屋久島などがある (半谷, 2008)。そういう調 査地では 1 年を通じて直接観察を行うことが でき, 霊長類の行動と生態を明らかにするこ とができる。

ところで哺乳類の食性を明らかにするには, 1) 直接観察, 2）粪分析, 3) 胃内容分析, 4) 安定同位体分析，5）DNA 分析，などの方法 がある。直接観察は実際に採食行動を確認し て定量することができる方法ではあるが，一 般的に野生哺乳類の直接観察は困難である。 この点で霊長類を対象にした食性調査は, 直 接観察調査を実施できる点で優れている。採 食行動は，各食物の採食時間割合で示される ことが普通であり，詳細に解析することで採 食生態の季節変異を明らかにすることができ るし (Hill, 1997; Agetsuma, 1995), 多地域を比 較することで地域変異を比較することができ る（Tsuji, 2010; 辻，2012）。ヤクシマザルの採 食生態を観察していると, キノコや昆虫に関 しては食べている時間や量はさほじ多くな かったとしても，個体によっては執着した食 べ方を示していた（Sawada et al., in press）。個 体識別することで主食となるような採食品目 だけでなく, マイナーな品目に関しても詳細 に議論できるかもしれない。

個体識別した個体群を長期的に調査するこ とによって, 個体の経年変化や家族の系譜を 終えることも, 霊長類を生態学的な研究沮上 にのせた際の長所である。屋久島の西部低地 林では, 1952 年に川村俊蔵・伊谷純一郎によ る最初の調査が行われ, 1976 年からは人付け による調査が開始された（Yamagiwa \& Hill, 1998; Yamagiwa, 2008)。群れと個体の長期的な 追跡調查が行われており，人口学的な動態や 
親子関係, 繁殖パラメタ, 野生群の分裂・融合・ 消滅過程などが明らかにされている（Takahata et al., 1994; Takahata et al., 1998a, b; Sugiura et al., 2002)。宮崎県の幸島においても 1953 年に 餌付けを開始して以来, 全頭を個体識別して ニホンザルの長期継続観察が行われている。

このような長期野生動物研究サイトは世界 の様々な地域にあり, 野生状態での長期生態 学的研究が行われ, 長期データが蓄積されつ つある。言うまでもないが世界の環境は安定 した系ではない。非定常的な状況における長 期生態学調査を継続しているものの, 変動の 大きな変化に対して霊長類がどう挙動するか はわかっていない。今後, 降雨量や平均気温 などの変動を伴う気候変動によって森林生態 系は大きく変容してゆくかもしれないし，人 為的攪乱によって森林が失われるかもしれな い。それらにともなって森林生態系における 生物種間関係が変化してゆくことが予想され る。このような長期にわたる非安定的な現象 をとらえるためには長期データの蓄積が必要 となるだろう。

国内の屋久島や金華山に生息するニホンザ ルだけでなく, 国外のマハレやボッソウなど の長期野生動物研究サイトでは, チンパンジー 個体の出生・移籍・死亡などに関する資料と 人口動態, 䧳の生活史, 繁殖状況の情報が蓄 積されている (Nishida et al., 2003; Sugiyama, 2004）。野生群の基礎資料は貴重であり, 公表 された論文（Nishida et al., 2003）は2000 年代 10 年間のアメリカ霊長類学会雑誌掲載論文の 中で被引用回数がトップとなった（保坂, 2013)。このような長期野外データがあってこ そ, 長期的な生態学的プロセスを評価するこ とができるのである。森林タイプが変化した ことを受けて霊長類の生態や行動がじう変化 してゆくのかを長期的な研究から明らかにす ることもできるし，重要な採食品目が失われ たり生まれたりすることで霊長類の生態や行 動がどう変化してゆくのかを明らかにするこ とができる。したがって, 現在得られている
このような基礎データを長期的に収集し続け ることがこれからの課題となるだろう。

一方で, 霊長類研究で欠けていると思われ る部分の一つは, システマティックなデータ 収集である。長期データは重要ではあるもの の，収集することは困難である。少なくとも 個人で 10 年以上にわたるデータを収集するこ とは難しく, チームを組んで調査地を運営し てゆか称ばならない。五百部（2013）は野外 霊長類研究の歴史を概観して, これからのア フリカでの類人猿研究の運営は「大企業の時 代」を迎えつつあると述べている。これまで の時代は, それぞれの調査地を維持するため の資金調達や許可申請, 基地の運営などを中 心となる日本人研究者が行い, 現地のアシス タントと共に自らが資料を収集し，その資料 を自ら分析して成果を公表してゆくといった 手法がとられていた（五百部，2013）。しかし ながら調查地運営と資金獲得を行う研究者は おおむね常勤職に就いているがゆえに，長期 で調査地に滞在することは難しく, データの 久損時期が生じることと, 調查地の運営自体 が頓挫する可能性があることが問題になる。 このような状況はいかにも自転車操業的で資 金的にも人的資本的にも長期継続は難しい。 したがってこれからの時代は長期データを安 定的に収集するために，あたかも大企業を経 営するかのように作業を分担して安定的に調 査地の運営とデータを収集できる仕組みを組 み立ててゆく必要があるだろう。

他にも基盤データの薄さが短所として挙げ られる。各種霊長類の生息密度や種間関係, 繁殖パラメタなどの生態的特性がどのように して決まっているのかを明らかにするために は, 霊長類が生息している森林の果実生産の 季節変化や地域変異との対応関係を検討する 必要がある。たとえば個体の繁殖成功度を高 めるための行動と環境条件との相互作用を研 究することで, 生態的特徵の進化要因を明ら かにすることができるだろう。そのためには, 困難な直接観察ではなく, ネストや食痕, 粪 
を用いた間接的な生息の証拠を基にして霊長 類の特徵（利用植生や食性など）の生態学的 なデータ収集を行うとともに，たとえば，数 十 $\mathrm{km}$ にわたるルートセンサスを行って果実の アベイラビリティや粪の収集を継続的に行っ ていかなければならない。屋久島と金華山で は前年の果実生産量とニホンザルの出産率と の関係が議論されているが (Suzuki et al., 1998)，こういう基盤データが常に収集され続 けることが約束されているわけではない。こ うした基盤データ収集作業は, 現地の調査助 手などに委託し, 果実生産の採食植物メニュー の季節変動だけではなく年変動を含む膨大な データを継続的に蓄積してゆく必要があるだ ろう。

ある調査サイトでの長期データだけでなく， 他地域の調査サイトと比較することができれ ば，より深い生態プロセスを追及することが できると思われる。たとえば森林の生産性や 生物多様性にかかわる基盤情報としては国際 長期生態学研究ネットワーク (ILTER:
International Long-Term Ecological Research Network）や日本では JaLTER（Japan Long Term Ecological Research) が主体となって，プ ロトコルを統一したデータを共有するネット ワークが形成されている（榎木ほか，2007; 新 山ほか, 2007; 岡部・小川, 2011)。霊長類研 究においても長期的生態プロセスを対象とす る研究者らが協力ネットワークを構築するこ とで, 長期的かつ大規模な調查・観測を推進 するとともに, 科学者や一般市民, 政策決定 者に対して情報公開と共有を行うことができ るようになるだろう。

\section{今後の可能性}

今後は, 霊長類を対象とした野外実験や基 盤データ, 調査ネットワーク, 新しい研究技術, メタ分析手法を併用することで, 研究の可能 性が広がってゆくだろう。しかしながら，現 状はグローバルに変動する自然環境と社会情 勢の中で, 霊長類のおよそ半数の種は狩猟や 生息地の消失などの人為的攪乱によって絶滅

\begin{tabular}{|c|c|c|c|}
\hline $\begin{array}{c}\text { その他 } \\
\text { 霊長類 }\end{array}$ & + & 0 & - \\
\hline+ & Mutualism & Not identified & Predation, Herbivory \\
& 相利共生 & 確認されていない & 捕食, 植食 \\
\hline 0 & Commensalism & Neutralism & Amensalism \\
\hline- & Predation, Parasitism & Amensalism & 片害 \\
\hline & 捕食, 寄生 & Competition \\
& 利係量 & 競争 \\
\hline
\end{tabular}

図 1 霊長類と他の生物との 2 種間関係。

適応度を基準にして両種が正の相互作用を受ける場合（相利共生）や片方の種のみが正の影響を受けてもう一方は 影響を受けない場合（片利共生）, どちらかが正の影響を受けもう一方は負の影響を受ける場合（捕食・寄生・植食 関係), 片方に負の影響があるもののもう一方には影響がない場合 (片害関係), 両種に負の影響がある場合 (競争 関係)，同所的に生息していながらもどちらにもめだった影響がない場合（無関係）がある。 
の危機にあり，その数は増加しつつある (Mittermeier et al., 2009)。人為的攪乱や土地利 用変化は霊長類や霊長類を中心とした生物間 相互作用にとって大きな影響を持っており， 長期野外調査は霊長類の保全を導く上での鍵 となる可能性がある。さらに野外実験やネッ トワークを併用することで, 複雑な現象や稀 な出来事, 空間的にも時間的にも変動量の大 きな生態学的現象をとらえられる可能性があ るので, 地域をまたいだ包括的な研究がなさ れるべきであろう。

生物間相互作用には捕食被食関係だけでな く，栄養のやり取りだけでない関係も存在す る。さらに霊長類を題材にした生態学的な研 究は, 捕食や競争などの直接的な関係だけで なく, 間接的な効果や副作用も醍醐味であり, 研究の幅には無限の可能性を秘めている。た とえば，森林生態系の種多様性維持に寄与す るCWDの重要性は世界的に認識されつつあ り（深澤・山下，2013）, 腐食連鎖系の基底資 源としての枯死木と霊長類の相互作用関係は 興味深い。しかしながら, 可能性が無限であっ てもアイデアがなければ拓くことはできない。 今後の霊長類を題材とした生態学では, 霊長 類学から生態学や他のフィールドに遭遇して 積極的に交わる機会を得ることで，分野横断 的な新しいアイデアにたどり着くことを期待 したい。

\section{謝辞}

本原稿の契機となった共同利用研究会を企 画・運営, さらに執筆の機会をくださった辻 大和氏と布施未恵子氏, 半谷吾郎氏にお礼を 申し上げます。

\section{引用文献}

Agetsuma N 1995: Dietary selection by Yakushima macaques (Macaca fuscata yakui): The influence of food availability and temperature. Int J Primatol 16: 611-627.
Agetsuma N, Nakagawa N 1998: Effects of habitat differences on feeding behaviors of Japanese monkeys: comparison between Yakushima and Kinkazan. Primates 39: 275-289.

Agetsuma N, Agetsuma-Yanagihara Y, Takafumi H 2011: Food habits of Japanese deer in an evergreen forest: Litter-feeding deer. Mamm Biol 76: 201-207.

Bravo SP, Zunino GE 1999: Germination of seeds from three species dispersed by black howler monkeys (Alouatta caraya). Folia Primatol 71: 342-345.

Begon M, HarperJL, Townsend CR 1996: Ecology (third edition). Blackwell Science, Oxford.

Butynski TM 1982: Vertebrate predation by primates: a review of hunting patterns and prey. J Hum Evol 11: 421-430.

Carton JM 1999: Digestive strategy of the Asian colobine genus Trachypithecus. Primates 40: 311-325.

Chapman CA 1989: Primate seed dispersal: The fate of dispersed seeds. Biotropica 21:148-154.

Chapman CA, Onderdonk DA 1998: Forests without primates: primate/plant codependency. Am J Primatol 45: 127-141.

Chapman CA, Bonnell TR, Gogarten JF, Lambert JE, Omeja PA, Twinomugisha D, Wasserman MD, Rothman JM 2013: Are Primates Ecosystem Engineers? Int J Primatol 34: 1-14.

Cords M 1986: Interspecific and intraspecific variation in diet of two forest guenons, Cercopithecus ascanius and C. mitis. J Anim Ecol 53: 811-827.

Corlett RT, Lucas PW 1990: Alternative seed-handling strategies in primates: seed-spitting by long-tailed macaques (Macaca fascicularis). Oecologia 82: 166171.

Dominy NJ, Duncan BW 2005: Seed-spitting primates and conservation and dispersion of large-seeded trees. Int J Primatol 26: 631-649.

Draper HH 1977: The aboriginal Eskimo diet in modern perspective. Am Anthropol 79: 309-316.

Elder WH, Elder NL 1970: Social groupings and the primate associations of the bushbuck (Tragelaphus scriptus). Mammalia 34: 356-363.

Eeley HAC, Foley RA 1999: Species richness, species range size and ecological specialisation among African primates: geographical patterns and conservation implications. Biodiv Cons 8: 1033-1056.

遠藤 秀紀 2002: 哺乳類の進化. 東京大学出版会, 383 pp.

榎木勉, 柴田 英昭, 日浦勉, 中静透 2007: 日本にお ける LTER の稼働 : 森林科学からのアプローチ. 日林誌 89: 311-313.

FitzGibbon CD 1990: Mixed-species grouping in Thomson's and Grant's gazelles: the antipredator 
benefits. Anim Behav 39: 1116-1126.

深澤 遊, 山下 聡 2013: 枯死木をめぐる生物間相互作 用: 企画趣旨と今後の展望. 日本生態学会誌 63 : 301-309.

Furuichi T 2006: Red-tailed monkeys (Cercopithecus ascanius) hunt green pigeons (Treron calva) in the Kalinzu Forest in Uganda. Primates 47: 174-176.

布施未恵子 2013: 昆虫食を通じて広がる世界一生態 系における霊長類昆虫食の役割一. 霊長類研究 29 : 105-121

Ganzhorn JU 1992: Leaf chemistry and the biomass of folivorous primates in tropical forests. Oecologia 91: 540-547.

Garber PA 1986: The ecology of seed dispersal in two species of callitrichid primates (Saguinus mystax and Saguinus fuscicollis). Am J Primatol 10: 155-170.

Gursky S 2000: Effect of seasonality on the behavior of an insectivorous primate, Tarsius spectrum. Int J Primatol 21: 477-495.

Gursky S 2002: Determinants of gregariousness in the spectral tarsier (Prosimian: Tarsius spectrum). J Zool 256: 401-410.

Hanya G 2004: Diet of a Japanese macaque troop in the coniferous forest of Yakushima. Int J Primatol 25: 5571.

Hanya G, Stevenson P, van Noordwijk M, Wong ST, Kanamori T, Kuze N, Aiba S, Chapman CA, van Schaik C 2011: Seasonality in fruit availability affects frugivorous primate biomass and species richness. Ecography 34: 1009-1017.

Hanson AM, Hodge KT, Porter LM 2003: Mycophagy among the Primates. Mycologist 17: 6-10.

半谷 吾郎 2008: 多様な植生帯への適応一二ホンザ ル. 高槻 成紀, 山極寿一編「日本の哺乳類学 2 中大型哺乳類 - 霊長類」東京大学出版会, 東京, pp. 252-272.

Hardie SM, Buchanan-Smith M 1997: Vigilance in single- and mixed-species groups of tamarins (Saguinus labiatus and Saguinus fuscicollis). Int J Primatol 2: 217-234.

Hill DA 1997: Seasonal variation in the feeding behavior and diet of Japanese macaques (Macaca fuscata yakui) in lowland forest of Yakushima. Am J Primatol 43: 305-322.

保坂 和彦 2013: 野生チンパンジーの長期研究から見 えてくるもの一狩猟・肉食行動をめぐって一. 生 物科学 64: 76-84.

五百部 裕 2000: アカコロブス対チンパンジー一霊長 類における食う一食われるの関係。（杉山幸丸編） 霊長類生態学, 京都大学学術出版会, pp. 61-84.

五百部裕 2013: 日本人研究者によるアフリカにおけ る野生霊長類研究の過去, 現在, そして未来. 生
物科学 64: 67-75.

Isbell LA 1990: Sudden short-term increase in mortality of vervet monkeys (Cercopithecus aethiops) due to leopard predation in Amboseli National Park, Kenya. Am J Primatol 21: 41-52.

Isbell LA 1994: Predation on primates: ecological patterns and evolutionary consequences. Evol Anthropol 3: 61-71.

Johnson CN 1996: Interactions between mammals and ectomycorrhizal fungi. Trend Ecol Evol 11: 503-507.

Julliot C 1997: Impact of seed dispersal by red howler monkeys Alouatta seniculus on the seedling population in the understorey of tropical rain forest. J Ecol 85: 431-440.

Kay RF 1984: On the use of anatomical features to infer foraging behabior in extinct primates. In Rodman PS \& Cant JGH (eds): Adaptations for foraging in nonhuman primates: Contributions to an organismal biology of prosimians, monkeys and apes, pp 21-53.

Lambert JE 1998: Primate digestion: Interactions among anatomy, physiology, and feeding ecology. Evol Anthropol 7: 8-20.

Lambert JE 1999: Seed handling in chimpanzees (Pan troglodytes) and redtail monkeys (Cercopithecus ascanius): implications for understanding hominoid and cercopithecine fruit-processing strategies and seed dispersal. Am J Phys Anthropol 109: 365-386.

MacIntosh AJJ 2014 : Ecology and Epidemiology of nematode infection in Japanese macaques: building an empirical model. 霊長類研究 30: 23-51.

Majoro B, Ventura R 2004: Apparent feeding association between Japanese macaques (Macaca fuscata yakui) and sika deer (Cervus nippon) living on Yakushima Island, Japan. Ethol Ecol Evol 16: 33-40.

McGrew WC 1974: Tool use by wild chimpanzees in feeding upon driver ants. J Hum Evol 3: 501-508.

Matsuda I, Murai T, Clauss M, Yamada T, Tuuga A, Bernard H, Higashi S 2011: Regurgitation and remastication in the foregut-fermenting proboscis monkey (Nasalis larvatus). Biol Lett (doi:10.1098/ rsbl.2011.0197).

松本 晶子 2013: サバンナに生息するヒヒの研究. 生 物科学 64: 95-104.

Mitani JC, Watts D 1999: Demographic influences on the hunting behavior of chimpanzees. Am J Phys Anthropol 109: 439-454.

Mitani JC, Sanders WJ, Lwanga JS, Windfelder TL 2001: Predatory behavior of crowned hawk-eagles (Stephanoaetus coronatus) in Kibale National Park, Uganda. Behav Ecol Sociobiol 49: 187-195.

Mittermeier RA, Wallis J, Rylands AB, Ganzhorn JU, Oates JF, Williamson EA, Palacios E, Heymann EW, 
Kierulff MCM, Long Yongcheng, Supriatna J, Roos C, Walker S, Cortés-Ortiz L, Schwitzer C 2009: Primates in Peril: The World's 25 Most Endangered Primates 2008-2010. IUCN/SSC Primate Specialist Group (PSG), International Primatological Society (IPS), and Conservation International (CI), Arlington, VA. 84pp.

Mowry CB, Decker BS, Shure DJ 1996: The role of phytochemistry in dietary choices of Tana River red colobus monkeys (Procolobus badius rufomitratus). Int J Primatol 17: 63-84.

Nathan R, Muller-Landau HG 2000: Spatial patterns of seed dispersal, their determinants and consequences for recruitment. Trend Ecol Evol 15: 278-285.

Newton PN 1989: Associations between langur monkeys (Presbytis entellus) and chital deer (Axis axis): chance encounters or a mutualism? Ethology 83: 89-120.

Newton P 1992: Feeding and ranging patterns of forest hanuman langurs (Presbytis entellus). Int J Primatol 13: 245-285.

新山馨, 武生 雅明, 河原崎 里恵 2007: データベース 化の鋼材一森林動態データベース（FDDB）を例 に一。 日本森林学会誌 89: 340-345.

Nishida T, Corp N, Hamai M, Hasegawa T, HiraiwaHasegawa M, Hosaka K, Hunt KD, Itoh N, Kawanaka K, Matsumoto-Oda A, Mitani JC, Nakamura M, Norikoshi K, Sakamaki T, Turner L, Uehara S, Zamma K 2003: Demography, female life history, and reproductive profiles among the chimpanzees of Mahale. Am J Primatol 59: 99-121.

西川 真理 2011: 屋久島に生息するニホンザルの亜種 ヤクシマザル (霊長目 : オナガザル科 : マカク属) による鳥類の卵および巣の捕食行動. 沖縄生物学 会誌 49: 57-64.

Noë R, Bshary R 1997: The formation of red colobusdiana monkey associations under predation pressure from chimpanzees. Proc R Soc Lond B 264: 253-259.

Oates JF, Whitesides GH, Davies AG, Waterman PG, Green SM, Dasilva GL, Mole S 1990: Determinants of variation in tropical forest primate biomass: new evidence from West Africa. Ecology 71: 328-343

大井徹 2013 : 採食行動の比較からツキノワグマと ニホンザルの種間関係を考える. 霊長類研究 29 : 123-135

岡部 貴美子, 小川 みふゆ2011: 森林の生物多様性モ ニタリングの歴史と生態学的視点からの将来展 望. 森林総合研究所研究報告 10: 231-250.

Otani T, Shibata E 2000: Seed dispersal and predation by Yakushima macaques, Macaca fuscata yakui, in a warm temperate forest of Yakushima Island, southern Japan. Ecol Res 15: 133-144.

Payne JB 1980: Competitors. In: Chivers DJ (ed.): Malayan Forest Primates, Springer US, pp. 261-277.
Porter LM 2001: Benefits of polyspecific associations for the goeldi's monkey (Callimico goeldii). Am J Primatol 54: 143-158.

Poulsen JR, Clark CJ, Smith TB 2001: Seed dispersal by a diurnal primate community in the Dja Reserve, Cameroon. J Trop Ecol 17: 787-808.

Sailer LD, Gaulin SJ, Boster JS, Kurland JA 1985: Measuring the relationship between dietary quality and body size in primates. Primates 26: 14-27.

佐藤 宏樹 2014: 種子散布者としての霊長類の役割 : 研究の現状と今後の課題. 霊長類研究 30: 53-78.

澤田 晶子 2014: 霊長類のキノコ食行動一今後の課 題と可能性一。霊長類研究 30: 5-21.

Sawada A, Sato H, Inoue E, Otani Y, Hanya G in press: Mycophagy among Japanese macaques in Yakushima: fungal species diversity and behavioral patterns. Primates. DOI 10.1007/s10329-0396-9.

Stanford CB 1998: Chimpanzee and red colobus: the ecology of predator and prey. Cambridge, MA: Harvard University Press.

Stanford CB, Nkurunungi JB 2006: Behavioral Ecology of Sympatric Chimpanzees and Gorillas in Bwindi Impenetrable National Park, Uganda: Diet. Int J Primatol 24: 901-918.

Stensland E, Angerbjörn A, Berggren P 2003: Mixed species groups in mammals. Mammal Review 33: 205223.

Stevenson PR 2000: Seed dispersal by woolly monkeys (Lagothrix lagothricha) at Tinigua National Park, Colombia: dispersal distance, germination rates, and dispersal quantity. Am J Primatol 50: 275-289.

Stevenson PR 2001: The relationship between fruit production and primate abundance in Neotropical communities. Biol J Linn Soc 72: 161-178.

Strier KB 2011: Primate Behavioral Ecology, 4th ed. New York, NY: Prentice Hall.

Sugiura H, Agetsuma N, Suzuki S 2002: Troop extinction and female fusion in wild Japanese macaques in Yakushima. Int J Primatol 23: 69-84.

Sugiyama Y 2004: Demographic parameters and life history of chimpanzees at Bossou, Guinea. Am J Phys Anthropol 124: 154-165.

Suzuki S, Hill DA, Maruhashi T, Tsukahara T 1990: Frogand lizard-eating behaviour of wild Japanese macaques in Yakushima, Japan. Primates 31: 421-426.

Suzuki S, Noma N, Izawa K 1998: Inter-annual variation of reproductive parameters and fruit availability in two populations of Japanese macaques. Primates 39: 313324.

Takahata Y, Suzuki S, Okayasu N, Hill D 1994: Troop extinction and fusion in wild Japanese macaques of Yakushima Island, Japan. Am J Primatol 33: 317-322. 
Takahata Y, Suzuki S, Okayasu N, Sugiura H, Takahashi H, Yamagiwa J, Izawa K, Agetsuma N, Hill D, Saito C, Sato S, Tanaka T, Sprague D 1998a: Does troop size of wild Japanese macaques influence birth rate and infant mortality in the absence of predators? Primates 39 : 245-251.

Takahata Y, Suzuki S, Agetsuma N, Okayasu N, Sugiura H, Takahashi H, Yamagiwa J, Izawa K, Furuichi T, Hill DA, Maruhashi T, Saito C, Saito S, Sprague DS 1998b: Reproduction of wild Japanese macaque females of Yakushima and Kinkazan Islands: a preliminary report. Primates 39: 339-349.

寺川眞理, 松井淳, 濱田知宏, 野間 直彦, 湯本 貴 和 2008: ニホンザル不在の種子島におけるヤマモ モの種子散布効果の減少. 保全生態学研究 13 : 161-167.

Terborgh J 1986: Community aspects of frugivory in tropical forests. In Estarada A, Fleming TH (eds): Frugivores and seed dispersal, Dr. W. Junk Publishers, Dordrecht, pp. 371-384.

Tutin CEG, Fernandez M, Rogers ME, Williamson AE, McGrew WC 1991: Foraging Profiles of Sympatric Lowland Gorillas and Chimpanzees in the Lope Reserve, Gabon [and Discussion]. Philosophical Transaction of the Royal Society London B 334: 179186.

Tsuji Y, Shimoda-Ishiguro M, Ohnishi N, Takatsuki S 2007: A friend in need is a friend indeed. Acta Theriol 52: 427-434.

辻 大和 2008: 霊長類と他の動物の混群現象について の研究の現状. 霊長類研究 24: 3-15.

Tsuji Y 2010: Regional, temporal, and interindividual variation in the feeding ecology of Japanese macaques. In: Nakagawa N, Nakamichi M, Sugiura N (eds.): Japanese Macaques, Springer, Tokyo, pp.99-127.

Tsuji Y, Sato K, Sato Y 2011: The role of Japanese macaques (Macaca fuscata) as endozoochorous seed dispersers on Kinkazan Island, northern Japan. Mamm Biol 76: 525-533.

辻 大和 2012: 二ホンザルの植生の種内変異一研究の 現状と課題一. 霊長類研究 28: 109-126.

Tsujino R, Yumoto T 2009: Topography-specific seed dispersal by Japanese macaques in a lowland forest on Yakushima Island, Japan. J Anim Ecol 78: 119-125.

Wang BC, Smith TB 2002: Closing the seed dispersal loop. Trend Ecol Evol 17: 379-385.

Waterman PG, Ross JAM, Bennett EL, Davies AG 1988: A comparison of the floristics and leaf chemistry of the tree flora in two Malaysian rain forests and the influence of leaf chemistry on populations of colobine monkeys in the Old World. Biol J Linn Soc 34:1-32.

Watts DP 1989: Ant eating behavior of mountain gorillas.
Primates 30: 121-125.

Wrangham RW, Bergmann-Riss E van Z 1990: Rates of predation on mammals by Gombe chimpanzees, 19721975. Primates 31: 157-170.

Yamagiwa J 2008: History and Present Scope of Field Studies on Macaca fuscata yakui at Yakushima Island, Japan. Int J Primatol 29: 49-64

Yamagiwa J, Hill DA 1998: Intraspecific variation in the social organization of Japanese macaques: past and present scope of field studies in natural habitats. Primates 39: 257-273.

Yamagiwa J, Mwanza N, Yumoto T, Maruhashi T 1991: Ant eating by eastern lowland gorillas. Primates 32: 247-253.

Yumoto T, Noma N, Maruhashi T 1998: Cheek-pouch dispersal of seeds by Japanese monkeys (Macaca fuscata yakui) on Yakushima Island, Japan. Primates 39: 325-338.

座馬耕一郎 2013: 霊長類とシラミの関係. 霊長類研 究 29: 87-103 
Summary

\section{Species Interactions and the Roles of Primates in the Ecosystem

\author{
Riyou TSUJINO ${ }^{1)}$, Takakazu YUMOTO ${ }^{2)}$ \\ 1) Center for Natural Environment Education, Nara University of Education \\ 2) Primate Research Institute Kyoto University
}

Primates are diverse regarding morphologically and ecologically. They play significant roles in the various niches of the ecosystem. In relation to the effects on the fitness, there are six possible combinations of biological interaction between primates and other species, ranging from harmful to mutually beneficial interactions and neutral interactions, such as predator-prey interaction (i.e., herbivory, predation and parasitism), competition, amensalism, mutualism, commensalism and neutralism, which result in the diverse species interactions. Therefore biological interactions between primates and other species have been studied. There are two major advantages in the ecological research of primates. Firstly, researchers are able to clarify detailed individual behaviours and ecological processes through the direct observation of primate individuals. Secondly, researchers are able to follow the secular trends of individual growth and/or lineages of blood relations through the long-term research of identified primate troops. We need further researches in the primate-other species interaction by applying field experiments, systematic background data, research networks, new research technology, meta-analysis methods, and transdisciplinary idea.

Key words: feeding habits, primates, species interaction, symbiosis

\begin{tabular}{|c|c|}
\hline 辻野亮 & $\begin{array}{l}\text { 奈良教育大学自然環境教育センター } \\
\text { † } 630-8528 \text { 奈良県奈良市高畑町 }\end{array}$ \\
\hline
\end{tabular}

Riyou TSUJINO Center for Natural Environment Education, Nara University of Education Takabatake-cho, Nara 630-8528 Japan

e-mail: tsujino@nara-edu.ac.jp 